\title{
A new species of Surazomus (Arachnida, Schizomida) from Brazilian Oriental Amazonia
}

\author{
Alexandre Bonaldo ${ }^{1} \&$ Ricardo Pinto-da-Rocha ${ }^{2}$ \\ ${ }^{1}$ Departamento de Zoologia, Campus de Pesquisa, Museu Paraense Emílio Goeldi. Avenida Perimetral, 66040-170 Belém, \\ Pará, Brasil. E-mail: bonaldo@museu-goeldi.br \\ 2 Departamento de Zoologia, Instituto de Biociências, Universidade de São Paulo. Rua do Matão, Travessa 14, 321, \\ 05508-900 São Paulo, São Paulo, Brasil. E-mail: ricrocha@usp.br
}

\begin{abstract}
Surazomus paitit sp. nov. is described from the Caxiuanã National Forest, State of Pará, Brazil. The new species resembles S. manaus Cokendolpher \& Reddell, 2000 and S. arboreus Cokendolpher \& Reddell, 2000 due to the shape of the male flagellum (with three projections on the posterior region and two dorsal depressions arranged in a row); it differs from them by the presence of two spurs on the pedipalpal femur (instead of a single one in S. arboreus and none in S. manaus), and by the male flagellum with slightly convergent sides posteriad (instead of parallel sides in S. manaus).

KEY WORDS. Caxiuanã National Forest; Hubbardiidae; litter fauna; Neotropical Region.
\end{abstract}

RESUMO. Uma espécie nova de Surazomus (Arachnida, Schizomida) da Amazônia Oriental Brasileira. Surazomus paitit sp. nov. é descrita da Floresta Nacional de Caxiuanã, Pará, Brasil. A espécie nova assemelha-se a S. manaus Cokendolpher \& Reddell, 2000 e a S. arboreus Cokendolpher \& Reddell, 2000 pela forma do flagelo do macho (com três projeções na região posterior e duas depressões dorsais em fila); difere destas pela presença de dois processos no fêmur do pedipalpo (ao invés de um único em S. arboreus e nenhum em S. manaus) e pelo flagelo do macho com lados levemente convergentes em sentido posterior (ao invés de lados paralelos em $S$. manaus).

PALAVRAS-CHAVE. Fauna de serapilheira; Floresta Nacional de Caxiuanã; Hubbardiidae; Região Neotropical.

Schizomids are poorly known arachnids probably due to their small size and very cryptic behavior. Nowadays, $218 \mathrm{ex}-$ tant species have been described, in two families. Only eight species have been recorded in Brazil, all belonging to Hubbardiidae (HaRvey 2003), one of them being a Caribbean species introduced into Rio de Janeiro (TourinHo \& KuRY 1999). The remaining Brazilian species occurs in the Amazon Basin, and have extremely restricted known distributions: Adisomus duckei Cokendolpher \& Reddell, 2000, from Reserva Florestal Adolfo Ducke, Manaus, Amazonas; Rowlandius sul Reddell \& Cokendolpher, 1995, known only by the holotype from Belém, Pará; and five species of Surazomus Reddell \& Cokendolpher, 1995, all recorded in the vicinities of Manaus (Reddell \& COKendolpher 2002, HaRvey 2003).

Despite the relative rarity of these animals in collections, the use of appropriate techniques, such as the Kempson and Winkler apparatus, for sampling upper soil layer and leaf litter fauna has revealed them to be much more common than previously known (see ADIs et al. 1999). A similar situation occurred in Australia, where until about 30 years ago no schizomid were recorded, and now 46 species are known (HaRvey 2003).
In this paper we describe a new species of Surazomus, a genus readily recognized by the flagellum shape (unsegmented, globose in males and three-segmented in females), and by the shape of the female spermathecae (with two pairs of lateral lobes, which are unequal in size). The new species, reported from six localities inside the Caxiuanã National Forest, represents the first record of this genus in Brazilian Oriental Amazonia.

The spermathecae were cleared with clove oil and examined on a slide under the microscope. The type material is deposited in the Museu Paraense Emilio Goeldi (MPEG, curator A. B. Bonaldo), Museu de Zoologia da Universidade de São Paulo (MZSP, curator R. Pinto-da-Rocha), and Texas Memorial Museum, The University of Texas at Austin (TMMC, curator J.C. Cokendolpher). All measurements are in millimeters.

\section{Surazomus paitit sp. nov.}

Figs 1-5

Type material. Male holotype from Parcela LBA $\left(1^{\circ} 44^{\prime}\right.$ 23.2"S, 51 $\left.27^{\circ} 70.8^{\prime \prime} \mathrm{W}\right)$, Estação Científica Ferreira Penna, Floresta Nacional de Caxiuanã, Melgaço, Pará, Brasil, J.A.P. Barreiros leg., 

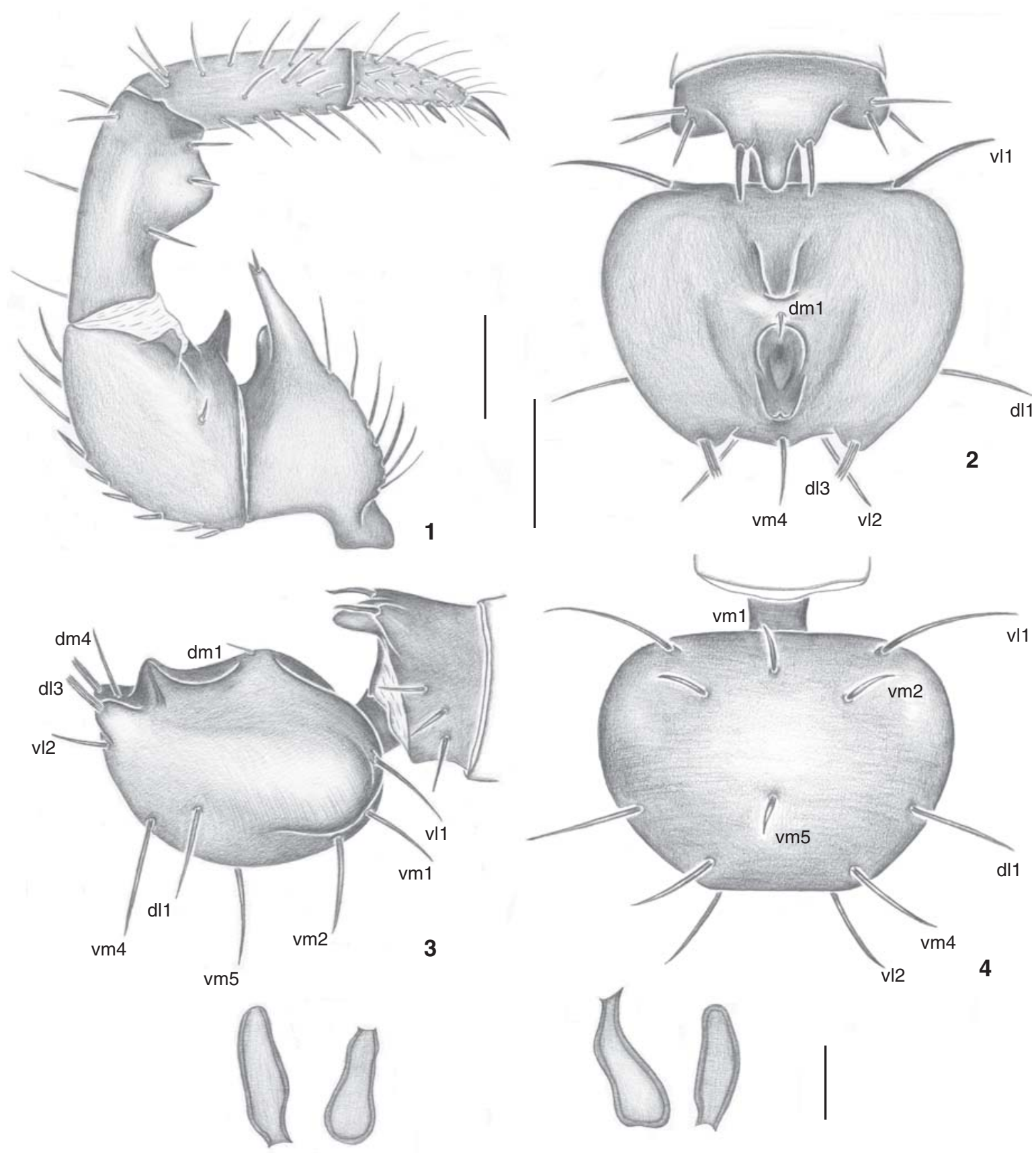

5

Figures 1-5. Surazomus paitit sp. nov. (1) Male pedipalp; (2-4) holotype male flagellum: (2) dorsal, (3) lateral, 4 ventral; (5) spermathecae (MPEG-19). (dl) Dorsal lateral seta, $(\mathrm{dm})$ dorsal central seta, $(\mathrm{vl})$ ventral lateral seta, $(\mathrm{vm})$ ventral central seta. Scale bars: $1,2-4=0.2 \mathrm{~mm}$; $5=0.02 \mathrm{~mm}$.

Revista Brasileira de Zoologia 24 (2): 323-326, junho 2007 
25-28.X.2003 (MPEG 030). Paratypes: BrazIL, Pará: Floresta Nacional de Caxiuanã, Parcela PPBio (Igarapé Caquajó, $1^{\circ} 57^{\prime} 38.9^{\prime \prime}$ S, $51^{\circ} 36^{\prime} 45.3^{\prime \prime}$ W), J.A.P. Barreiros \& D.F. Candiani leg., 1 male, 1 female, 08-13.V.2005 (MPEG 029, 035); Estação Científica Ferreira Penna (Parcela LBA, $1^{\circ} 44^{\prime} 23.2^{\prime \prime}$, $51^{\circ} 27^{\prime} 70.8^{\prime \prime}$ W), J. A. P. Barreiros leg., 1 female, 08-11.VIII.2003 (MPEG 001); 1 male, 20-23.VIII.2003 (MPEG 002); 1 female, 1 immature, 25-28.V.2003 (MZSP 27808, MPEG 005); 1 female, 21-23.III.2003, (MPEG 004); 1 female, 19-22.X.2003 (TMMC); 2 males, 1 female, 2 immatures, 25-31.X.2003 (MPEG 007, 008, 009, TMMC); (Parcela Estação, $1^{\circ} 44^{\prime} 22.7^{\prime \prime}$ S, 512ㄱ'27.9”W), A. B. Bonaldo \& J. A. P. Barreiros leg., 1 male, 1 female, 05-22.IV.2002 (MPEG 011, 012); 1 male, 1 female, 3 immatures, 27-30.X.2003 (MPEG 013, 016, 019, 023, 026); 1 immature, 02.XI.2002 (MPEG 015); 2 females, 1 immature, 08-16.VII.2002 (MPEG 017, 020, 037); 1 immature, 11.VIII.2002 (MPEG 024); M. Zanuto leg., 1 male, 14-15.VIII.1996 (MPEG 032); A.B. Bonaldo \& J.A.P. Barreiros leg. (Igarapé Puraquequara, $\left.1^{\circ} 44^{\prime} 60.3^{\prime \prime} \mathrm{S}, 51^{\circ} 28^{\prime} 38.6^{\prime \prime} \mathrm{W}\right), 1 \mathrm{im}-$ mature, 24-27.X.2003 (MPEG 014); 1 male, 08-16.VII.2002 (MPEG 018); 1 male, 24.X-03.XI.2003 (MPEG 034); (Igarapé Curuazinho, $\left.1^{\circ} 44^{\prime} 20.3^{\prime \prime} \mathrm{S}, 51^{\circ} 25^{\prime} 85.2^{\prime \prime} \mathrm{W}\right), 2$ females, 1 immature, 02.XI.2002 (MPEG 021); 1 male, 08-16.VII.2002 (MPEG 025); 1 female, 21-31.X.2003 (MPEG 036); (Caiçara, 166'63.6"S, $51^{\circ} 25^{\prime} 44.8^{\prime \prime} \mathrm{W}$ ), 1 female, 31.X-3.XI.2003 (MPEG 027); 4 males, 21-31.X.2003 (MZSP 27809, MPEG 033).

Etymology: the specific name is a transcription of the Mundurucú words Pã and Itit, which stands for small (itit literally, son of the son), flexible, thumb-like animal (pã). The Mundurucú people are one of the major indigenous cultures from Brazilian Oriental Amazonia.

Diagnosis. Surazomus paitit sp. nov. resembles $S$. manaus Cokendolpher and Reddell, 2000 and S. arboreus Cokendolpher and Reddell, 2000 due to the shape of the male flagellum (with three projections on the posterior region and dorsal depressions arranged in a row); it differs from them by the presence of two spurs on the pedipalpal femur (instead of a single one in S. arboreus and none in S. manaus), and by the male flagellum with slightly convergent sides posteriad (instead of parallel sides in S. manaus).

Description. Holotype (MPEG 030). Male 3.25 long; greenish brown, venter of body, tarsi legs and flagellum yellowish brown.

Cephalothorax. Propeltidium long, wide, with longitudinal row of two setae on anterior process and three pairs of dorsal setae. Eyespot distinct, elongate oval, close to anterior margin of propeltidium. Metapeltidium divided by narrow white line. Anterior sternum with 12 setae.

Abdomen. Tergites I-VII with one pair of large dorsal setae each; VIII-IX with one pair of dorsolateral setae and one pair of lateral setae; X-XI narrow, with one pair of dorsal setae each. Segments X-XI telescoped; segment XII heavily sclerotized. Posterodorsal apophysis conical. Flagellum (Figs 2-4) unsegmented, with short stalk; two deep dorsal depressions (anterior larger) bordered by heavily sclerotized ridges posteriorly and laterally; lateral margin converging posteriad; posterolateral corners with brush of three long and thin setae in place of dl3 seta.

Chelicerae. Fixed finger digit with four smaller denticles between two primary teeth. Movable digit: serrula with 14 teeth, guard tooth present; without accessory teeth. Setae $1=3,2=4$, $3=3,4=6$ long dorsally, $5=8,6=1$.

Pedipalps (Fig. 1): Trochanter with one large ectal spur without setae on apex (about 0.70 of trochanter-femur joint width) and one small mesal spur; femur with two spurs (ectal and mesal larger); patella curved with ventral knob.

Legs. Tarsal segment proportions: 11:1:2:2:2:2:2:5. Anterior dorsal margin of femur IV produced at about 90 angle, about 2.3 times as long as high.

Measurements. Pedipalp: trochanter 0.25; femur 0.52; patella 0.47 ; tibia 0.4 ; tarsus 0.15 ; total 1.79 . Leg I: trochanter 0.22 ; femur 0.77 ; patella 1.05 ; tibia 0.75 ; basitarsus 0.27 ; telotarsus 0.4; total 3.46. Leg II: trochanter 0.12 ; femur 0.6; patella 0.35 ; tibia 0.3 ; basitarsus 0.35 ; telotarsus 0.27 ; total 1.99 . Leg III: trochanter 0.12 ; femur 0.52 ; patella 0.22 ; tibia 0.27 ; basitarsus 0.3 ; telotarsus 0.25 ; total 1.68. Leg IV: trochanter 0.22 ; femur 0.95 ; patella 0.4; tibia 0.6; basitarsus 0.52 ; telotarsus 0.3 ; total 2.99 .

Female paratype (MZSP-27807). As in male except as follows: body 3.5 long; propeltidium 0.97 long. Anterior sternum with 10 setae. Pedipalps: Trochanter unarmed, with five ventrolateral setae; femur unarmed; patella knob reduced. Leg I tarsi proportion: 10:1:2:2:2:2:5. Flagellum: three-segmented. Spermathecae (Fig. 5): With two pairs of lobes with wide stalks enlarging distally to rounded end. Gonopod absent. Measurements: pedipalp - trochanter 0.17; femur 0.42; patella 0.4 ; tibia 0.3 ; tarsus 0.17 ; total 1.99. Leg I: trochanter 0.17 ; femur 0.72 ; patella 0.9 ; tibia 0.55 ; basitarsus 0.25 ; telotarsus 0.35 ; total 2.94 . Leg II: trochanter 0.1 ; femur 0.55 ; patella 0.27 ; tíbia 0.27 ; basitarsus 0.27 ; telotarsus 0.25 ; total 1.44 . Leg III: trochanter 0.1 ; femur 0.52 ; patella 0.2 ; tibia 0.17 ; basitarsus 0.25 ; telotarsus 0.27 ; total 1.51. Leg IV: trochanter 0.25 ; femur 0.6 ; patella 0.3 ; tibia 0.52 ; basitarsus 0.42 ; telotarsus 0.3 ; total 2.39 .

Variation. Total length (including flagellum) 3.15-3.7 long in males; 2.4-3.15 long in females. The retrolateral tubercle on pedipalpal femur is much smaller or rounded in a few males.

Biological notes. All specimens studied were captured with Winkler apparatus in primary upland Amazonian Rain forest (Terra Firme). The sex ratio observed was 1:1, the same as observed for the Peruvian Surazomus chavin (see PINTO-DA-RochA 1996), and contrasting with the Central Amazonian species $S$. brasiliensis in which more females were found (ADIs et al. 1999).

\section{ACKNOWLEDGEMENTS}

We thank José A.P. Barreiros (MPEG) for information on collected material and linguist Gessiane Picanço (MPEG) for help with the Mundurucú language. Collecting support was provided by the Multi-taxonomic Inventory of Caxiuanã National Forest (PNOPG/CNPq) and PPBio (Programa de Pesquisa 
em Biodiversidade - MPEG/MCT). PPBio also sponsored a RPR trip to Belém, during which this paper was written. The authors were supported by the CNPq (ABB PQ grant \#303591/ 2006-3; RPR PQ grant \#476523/2003-6).

\section{REFERENCES}

Adis, J; J. Reddell; J. Cokendolpher \& J.W. Morais. 1999. Abundance and phenology of Schizomida (Arachnida) from a primary upland forest in central Amazonia. Journal of Arachnology 27: 205-210.

Harvey, M.S. 2003. Catalogue of the smaller Arachnid orders of the World. Collingwood, Csiro Publishing. 385p.
Pinto-DA-Rocha, R. 1996. Surazomus chavin new species, first Schizomida (Hubbardiidae, Hubbardiinae) described from Peru. Journal of Arachnology 24: 265-267.

Tourinho, A.L.M. \& A.B. KurY, 1999. The Southernmost record of Schizomida in south America, first record of Schizomida for Rio de Janeiro and of Stenochrus Chamberlin, 1922 for Brazil (Arachnida, Schizomida, Hubbardiidae). Boletim do Museu Nacional, Série Zoologia 405: 1-6.

Reddell, J.R. \& J. Cokendolpher. 2002. Schizomida, p. 387-398. In: J. AdIs (Ed.) Amazonian Arachnida and Myriapoda keys for the identification to classes, orders, families, some genera, and lists of known species. Sofia, Pensoft, 590p.

Received in 22.XI.2006; accepted in 28.IV.2007.

Revista Brasileira de Zoologia 24 (2): 323-326, junho 2007 